\title{
Studi Pendahuluan tentang Perspektif Ilmuwan Islam dan Katolik dalam Dilema Etika Surplus Embrio serta Opsi Pemecahan Masalahnya
}

\author{
Agung Dewanto ${ }^{\mathrm{I}, 4}$, Ita Fauzia Hanoum ${ }^{\mathrm{I}}$, Diany Ayu Suryaningtyas ${ }^{\mathrm{I}}$, Shofwal Widad ${ }^{\mathrm{T}}$, Ihsan Yudhitama², \\ Galuh Dyah Fatmala3, Ahmad Muzakky³

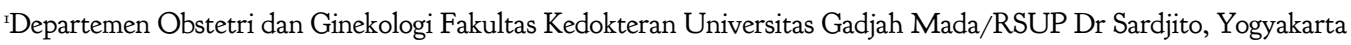 \\ ${ }^{2}$ Dokter Alumni Fakultas Kedokteran Universitas Gadjah Mada \\ ${ }^{3}$ Sarjana Kedokteran Fakultas Kedokteran Universitas Gadjah Mada \\ ${ }^{4}$ Program S2 Bioetika, Pasca Sarjana UGM
}

\author{
Kata Kunci \\ Surplus embrio, donasi embrio, \\ teknologi reproduksi berbantu, dilema \\ etik

\section{Korespondensi \\ agungdewanto2009@gmail.com \\ Publikasi \\ (C) 20I8 JEKI/ilmiah.id \\ DOI \\ Io.26880/jeki.v2i2.20}

Tanggal masuk: I4 April 20I8

Tanggal ditelaah: 6 Mei 2018

Tanggal diterima: 10 Mei 2018

Tanggal publikasi: 12 Juni 2018
Abstrak Latar Belakang: Teknologi reproduksi berbantu sudah berkembang di Indonesia dan banyak membantu masyarakat dalam memperoleh kehamilan. Surplus embrio dari proses simpan beku merupakan konsekuensi kemajuan teknologi ini sendiri. Dilema etika muncul tentang bagaimana sebaiknya mengelola surplus embrio. Di sisi lain, peraturan perundangan di Indonesia saat ini hanya memperbolehkan untuk memperpanjang masa penyimpanan atau membuang surplus embrio.

Metode: Metode penelitian menggunakan Participant of doservation dengan purposive sampling Penelitian ini merupakan intisari pemikiran dari ilmuwan dan pegiat bioetika di Indonesia yang dikemukakan dalam Seminar dan Diskusi Bioetika dalam Pelayanan Teknologi Reproduksi Berbantu, Agustus 2016 di Yogyakarta.

Hasil: Pertimbangan etika tentang bagaimana sebaiknya surplus embrio diperlakukan dibahas oleh tiga ilmuwan dengan latar belakang agamawan, Prof. Jenie dan Prof. Almirzanah beragama Islam sedangkan Dr. Kusmaryanto beragama Katolik. Ketiganya berpendapat bahwa solusi manajemen surplus embrio sangat erat kaitannya dengan diskursus agama. Ketiganya menyatakan bahwa status moral dari embrio penting dipahami sebagai landasan sikap terhadap surplus embrio. Pemusnahan embrio dianggap tidak etis oleh ketiga ilmuwan. Ketiganya menyetujui donasi embrio untuk pasangan infertil lain dengan penyesuaian aturan terhadap kearifan lokal Indonesia. Selanjutnya, Prof. Umar dan Prof. Almirzanah memandang penggunaan surplus embrio untuk penelitian masih kontroversial namun tidak menutup kemungkinan diperbolehkan dengan berbagai syarat dan memperhatikan konteks serta asas kemanfaatan. Sedangkan Dr. Kusmaryanto menyatakan ketidaksetujuan surplus embrio untuk penelitian atas dasar interpretasi bahwa embrio mempunyai makna intrinsik yang harus dilindungi.

Kesimpulan: Latar belakang agama mempengaruhi perspektif ilmuwan tentang bagaimana memandang status embrio dan pilihan tindakan terhadap surplus embrio. Perlu dilakukan penelitian mendalam multidisipliner dari klinisi, agamawan, ilmuwan, pakar hukum dan pasien untuk mengakomodasi pilihan tindakan terhadap surplus embrio di Indonesia.

Abstract Background: Assisted Reproductive Technology (ART) has been well developed in Indonesia to encourage better pregnancy rate. Surplus embrio from cryopreservation techniques comes up as the consequence of the technology itself. We are facing ethical dilema on how to manage the surplus embryo while the regulation only provides options to either prolong storage time or to dispose the embryo.

Method: Participant of observation and purposive sampling method has been used for this research. This article was written based on Indonesia scientists' comments at Bioethics Discussion on Assisted Reproductive Technology, on August 2016 in Yogyakarta.

Result: The three scientists on this study have background of religious scholar; Prof. Jenie and Prof. Almirzanah are Muslims while Dr. Kusmaryanto is Catholic. They believed in the important role of religion to give solution regarding surplus embryo management. Understanding the status of embryo was required to emphasis the option of surplus embryo management. They thought embryo disposal was unethical while embryo donation to other couple was ethically acceptable, with the need to accommodate local policy. Prof. Jenie and Prof. Almirzanah stated the possibility of using surplus embryo for research with some precautions. On the other hand, Dr. Kusmaryanto expresed disagreement to use surplus embryo for research, based on the interpretation that the intrinsic meaning of embryo must be protected.

Conclusion: Religion influences the perspective of scholars on how to see the status of embryo and how to manage the surplus embryo. Future study is needed to solve the ethical dilemma of surplus embryo management in Indonesia through multidisciplinary collaboration approach. 


\section{PENDAHULUAN}

Kesuksesan laboratorium In Vitro Fertilization (IVF) yang ditunjang dengan teknik simpan beku dan keberhasilan kehamilan pada pasangan infertil kemudian menyisakan beberapa hal yang belum pernah atau enggan dibicarakan sebelumnya di Indonesia. Hal tersebut antara lain adalah embrio kualitas baik yang tidak (belum) dikembalikan ke dalam rahim istri. Menurut Human Fertilisation and Embriology Authority (HFEA) (sebuah organisasi di Inggris yang mengatur klinik infertilitas dan riset embrio manusia) surplus embrio adalah embrio yang dihasilkan dari prosedur IVF yang tidak dikembalikan ke rahim (ibu genetiknya) yang selanjutnya embrio ini tidak memiliki harapan pada masa depannya. ${ }^{1}$ Terjadinya surplus embrio disebabkan oleh: 1) dampak stimulasi pada indung telur untuk mendapatkan jumlah telur lebih banyak saat pengambilan telur, sehingga menjadi lebih efisien untuk mendapatkan embrio yang berkualitas baik dan angka keberhasilan kehamilan lebih tinggi, 2) ibu sudah tidak menghendaki hamil lagi karena keberhasilan kehamilan pada program IVF sebelumnya, sementara masih memiliki embrio simpan beku di Klinik IVF, 3) pasangan sudah bercerai, 4) embrio tidak dapat ditransfer ke ibu karena sakit atau kecelakaan, 5) karena alasan pribadi, ibu tidak menghendaki embrio ditransfer ke uterusnya, dan 6) ibu meninggal dunia.

Solusi untuk surplus embrio berdasarkan Permenkes no. 43 tahun 2015 pasal 14 menyatakan bahwa kelebihan embrio ditransfer ke rahim istri paling lama dalam waktu 2 tahun, kecuali pasangan suami istri meminta untuk memperpanjang penyimpanan embrio. ${ }^{2}$
Peraturan tentang surplus embrio juga diatur dalam Peraturan pemerintah no. 61 tahun 2014 yang menyatakan kelebihan embrio dapat diperpanjang setiap 1 tahun untuk kepentingan kehamilan selanjutnya. ${ }^{3}$ Pada pasal 43 selanjutnya menjelaskan kelebihan embrio dilarang ditanam pada rahim ibu jika ayah meninggal atau bercerai dan tidak diperkenankan ditanam di rahim perempuan lain. Jika kemudian pasangan suami istri tidak memperpanjang masa penyimpanan embrio maka penyelenggara ART harus memusnahkan kelebihan embrio.

Peraturan di Indonesia hanya menyediakan dua opsi pada manajemen surplus embrio yaitu perpanjangan atau pemusnahan surplus embrio simpan beku. Pilihan pemusnahan surplus embrio akan memicu dilema etika tergantung bagaimana persepsi terhadap status embrio itu. Perlu dilakukan penelitian lebih lanjut mengenai pertimbangan etika surplus embrio, opsi-opsi penatalaksanaan dan solusinya.

\section{TINJAUAN PUSTAKA}

Kerridge et al. tahun 2010 meneliti tentang pandangan tokoh agama terhadap manajemen surplus embrio (tabel 1). Penelitian ini merupakan hasil wawancara tokoh-tokoh agama Budha, Katolik, Hindu, Islam, EvangelicalProtestan dan Yahudi tentang donasi dan penelitian embrio. Dalam penelitian tersebut dikatakan hanya tokoh Islam yang menolak opsi donasi untuk pasangan infertil lain. Untuk pilihan menyimpan embrio selamanya, tokoh agama Katolik menolak dan tokoh Yahudi membolehkan sedangkan agama lain tidak memberikan tanggapan. ${ }^{4}$

Tabel 1. Pandangan agama terhadap manajemen surplus embrio (disarikan dari Kerridge et al, 2010) ${ }^{4}$

\begin{tabular}{|c|c|c|c|c|}
\hline Agama & Memusnahkan & Donasi penelitian & Donasi pasangan lain & Disimpan selamanya \\
\hline Tokoh Budha & Menolak & Setuju & Setuju & $?$ \\
\hline Tokoh Katolik & Menolak & Menolak & Lebih baik & Menolak \\
\hline Tokoh Hindu & Menolak & Setuju & Setuju & $?$ \\
\hline Tokoh Islam & \multicolumn{2}{|c|}{ Tergantung mazhab } & menolak & $?$ \\
\hline $\begin{array}{l}\text { Tokoh Evangelical- } \\
\text { protestan }\end{array}$ & \multicolumn{4}{|c|}{$\begin{array}{l}\text { Terkesan memberikan pilihan pada pasangan dengan himbauan sudah mendapatkan informasi baik } \\
\text { dari konselor kesehatan ataupun gereja }\end{array}$} \\
\hline Tokoh Yahudi & Menolak & Setuju & Setuju & Setuju \\
\hline
\end{tabular}


Pilihan-pilihan pengelolaan surplus embrio di Laboratorium IVF di berbagai Negara.

Sebagaimana telah ditulis di berbagai penelitian yang dilakukan pada berbagai negara seperti Swedia dan Australia dan diterbitkan dalam jurnal ilmiah internasional, disebutkan ada berbagai pilihan pasien yang bisa diterapkan dalam pengelolaan surplus embrio, di antaranya adalah:

1. Pemusnahan embrio. ${ }^{5}$

2. Donasi kepada pasangan infertil untuk mendapatkan kehamilan dan bayi. ${ }^{5}$

3. Donasi untuk riset (stem cell, perkembangan embrio, dan organ tubuh). ${ }^{5,6}$

4. Donasi untuk training kandidat embriolog atau mahasiswa kedokteran. ${ }^{5}$

Berdasarkan Banker et al. tahun 2013 dalam laporan pengelolaan IVF di berbagai negara menyatakan bahwa penetapan aturan mengenai IVF dan surplus embrio dipengaruhi oleh faktor ideologi agama, budaya, politik dan pembuat kebijakan kesehatan. ${ }^{7}$ Hal tersebut ditegaskan kembali dalam pembaharuan laporan tahun 2016. ${ }^{8}$ Berdasarkan laporan tersebut, Indonesia merupakan negara yang paling singkat memberi waktu penyimpanan embrio (2 tahun) sedangkan negara lain seperti Australia, Inggris, Israel, dan Turki memberi waktu sampai 5 tahun atau lebih, bahkan Arab Saudi tidak memberi batasan waktu. Memang masih ada kesempatan memperpanjang waktu penyimpanan bagi pasangan yang menginginkannya. Negara yang mayoritas penduduknya beragama Islam seperti Arab Saudi dan Turki tidak memperbolehkan donasi embrio, begitu pula penggunaan surplus embrio untuk penelitian. Namun Arab Saudi masih membuka peluang penggunaan embrio untuk penelitian dengan batasan-batasan yang ketat. $^{8}$

Peraturan yang mengatur surplus embrio juga belum dapat mewadahi kemajemukan Indonesia yang memiliki bermacam agama, etnis, dan suku bangsa. Kemajemukan latar belakang ini tidak hanya terdapat pada pasangan infertil tetapi juga pada pemberi layanan IVF yaitu dokter, embriolog, teknisi laboratorium, dan perawat. Ketidaksepakatan dalam mengatur kelebihan embrio dapat mengganggu pelayanan prosedur IVF selanjutnya. Di Malaysia, beberapa pemuka agama yang mewakili agama yang berbeda memiliki pendapat yang berbedabeda pula pada donasi embrio untuk penelitian stem cell. ${ }^{9}$

\section{METODE PENELITIAN}

Metode penelitian menggunakan Participant of observation dengan purposive sampling. Penelitian ini merupakan hasil Seminar dan Diskusi Bioetika dalam Pelayanan Teknologi Reproduksi Berbantu yang dilaksanakan di RSUP Dr. Sardjito, Yogyakarta pada tanggal 2 Agustus 2016 yang dihadiri oleh staf Klinik Permata Hati, residen dan klinisi yang diundang, serta panelis yang merupakan ilmuwan dan pegiat bioetika.

\section{HASIL DAN PEMBAHASAN}

\section{Pertimbangan Etika Pada Pilihan Pemusnahan Embrio}

Status embrio menjadi perdebatan dan diskusi panjang. Ilmuwan dan bioetikawan Dr. Kusmaryanto sekaligus seorang pemuka agama Katolik menyatakan bahwa embrio memiliki hak hidupnya sejak saat konsepsi.

“.... semua agama, ini menganggap bahwasanya embrio itu adalah person sejak konsepsi. Ya, meskipun kalau Prof Umar dari muslim mungkin mengatakan baru ada nyawanya kalau empat bulan, kalau dari Katolik sejak konsepsi."(669)

"Mayo clinic (Amerika Serikat) juga mengatakan life itu dimulai dari saat terjadinya konsepsi. Harvard mengatakan, individual of a new life begins at conception. Semua at conception."(776)

Menurut Dr. Kusmaryanto seharusnya tidak ada tindakan apa pun yang bisa menghentikan kehidupan embrio. Pemusnahan kelebihan embrio bertentangan dengan konsep kepercayaan agama Katolik.

"kalau kita mau buang, jelas ini (geleng kepala) is not that way. Mengapa demikian? Karena kita semua orang beriman, manusia itu diciptakan oleh Allah, termasuk embrio itu, diciptakan oleh Allah oleh karenanya kalau kita merusak embrio berarti merusak ciptaan Allah. Dengan 
kata lain menempatkan manusia lebih tinggi daripada Allah itu sendiri."(1178)

Sementara itu, ilmuwan dari Universitas Islam Negeri Sunan Kalijaga Yogyakarta, Prof. Almirzanah menyatakan bahwa masih ada pilihan lain yang lebih baik selain pemusnahan kelebihan embrio. Status embrio dapat dianggap sebagai 'person' dan juga sebagai harta (kepemilikan).

"Ada 3 option paling tidak di situ option pertama adalah mau dibuang begitu saja ..... Yang kedua .... embrio adoption atau embrio donation .... Yang ketiga adalah untuk embrio research. Nah itu saya kira juga tidak mudah. Tinggal bagaimana nanti kita memperlakukan apa sih status dari embrio itu."(836)

"Sudut pandang saya begini, mungkin agak berbeda mengenai embrio adoption ..... kalau buat saya yang namanya creation, saya mengajar tasawwuf ya jadi saya ambil konsep dari itu, creation itu adalah self disclosure of God. Bahwa ciptaan itu adalah penampakan diri Tuhan....., maka segala sesuatu sekecil apa pun itu punya intrinsic meaning. Itu saya kira akan luar biasa efeknya nanti...."(931)

"Nah sekarang kembali kepada status embrio tadi. Orang berdebat itu sebagai person ataukah itu sebagai harta... ada kasus pasangan Argentina menunggu lahir embrio (ART) itu sementara ketika pulang ke Argentina dia clash (cerai) dia orang kaya raya lalu hartanya mau diwariskan ke mana? Embrionya itu kita anggap sebagai person atau sebagai kekayaan. Kalau sebagai person dia yang mendapat warisan tetapi kalau sebagai kekayaan justru dia yang juga ikut diwariskan. Maka saya pakai pendekatan bahwa segala sesuatu apa pun kecilnya itu have an intrinsic meaning jadi otomatis di sini disposal tadi dibuang begitu saja itu mungkin tidak akan kita lakukan gitu."(939)

Di dalam Islam terdapat beberapa mazhab atau sekte misalnya Syiah, Sunni dan banyak lagi yang lain. Beberapa mazhab seperti Syiah memberi peluang dan opsi lebih longgar dalam pengelolaan surplus embrio. Pemilihan pengelolaan kelebihan embrio seharusnya mempertimbangkan pilihan yang lebih banyak memberi keuntungan daripada kerugian. Masih mengutip komentar Prof. Almirzanah, beliau berkata:

Kalo dunia sunni memang third party itu dilarang. Sama sekali tidak boleh. Cuma kalo di syiah itu ada lowongan gitu ya. Karena syiah ... more liberal karena memang ijtihadnya mereka third party itu dibolehkan dalam kondisi tertentu.... disebut dengan temporal married, Mut'ah."(854)

Selanjutnya, Prof. Umar Anggara Jenie mengutip pendapat Jumhur Ulama (konsensus sebagian besar ulama di kalangan Muslim) berdasarkan interpretasi terhadap sebuah hadits yang menyatakan bahwa embrio adalah makhluk hidup, namun belum ditiupkan ruh sampai usia 120 hari setelah konsepsi. Setelah 120 hari, embrio menjadi mendapat status "insan".

"Hadist Rasulullah mengatakan ensoulment atau masuknya nyawa itu adalah pada hari ke 120. Ketika ensoulment itu terjadi, itulah alinsan artinya sudah ada amanah kekhalifahan di situ. Nah dalam hal ini, teman-teman syiah sebelum ada ensoulment, maka embrio itu ya makhluk biasa saja. Bisa digunakan untuk research bisa digunakan untuk macammacam tidak masalah. Tetapi bagi orang yang mengatakan apa pun juga itu makhluk hidup, membunuh makhluk hidup itu adalah suatu hal tindakan yang salah. Jadi kembali ini menjadi suatu dilema."(989)

"Kalau menurut saya, saya tetap perasaan dan keagamaan itu tentu ikut berbicara dan nasab itu sangat penting sekali maka ART kita support sejauh itu donor terhadap donornya berasal dari pasangan suami istri... Kalau bisa didonorkan ya didonorkan. Tetapi kalaui di-destroy saya belum bisa memberikan jawabannya.... Kalau research itu digunakan untuk saving untuk menolong manusia banyak dengan keberhasilan yang sudah meyakinkan maka itu diizinkan..."(1047)

Kedua cendekiawan terakhir disebut cenderung untuk menolak pula opsi pemusnahan embrio. Keduanya berlatar belakang cendekiawan muslim.

Agama tampaknya mempengaruhi para cendekiawan Indonesia dalam memberi opini pada opsi pemusnahan embrio dalam kasus 
surplus embrio. Selain karena salah satu dari mereka adalah pemuka agama, beberapa dari mereka berasal dari universitas berbasis agama. Di sisi lain, pemusnahan embrio adalah tidak beretika. Dasar penolakan mereka adalah status moral embrio. Pemusnahan embrio dipandang tidak etis oleh berbagai kalangan akademisi.

Pilihan pemusnahan embrio rupanya cenderung tidak popular di kalangan pasien. Bahkan ada sebagian pasien yang awalnya memilih untuk memusnahkan embrionya, namun pada beberapa tahun kemudian mereka berganti pilihan. ${ }^{10}$ Kami belum mengetahui apakah pasien yang memiliki kelebihan embrio simpan beku di laboratorium Permata Hati memiliki permasalahan serupa.

\section{Pertimbangan Etika Pada Pilihan Donasi Embrio Pada Pasangan (Menikah) Infertil}

Setelah pemusnahan embrio dianggap tidak etis oleh berbagai kalangan akademisi, opsi yang umumnya dipilih adalah donasi embrio pada pasangan infertil. Di Indonesia pasangan tidak menikah tidak diperbolehkan mengikuti program IVF sehingga embrio tidak bisa didonasikan pada pasangan infertil yang tidak menikah. Prof. Jenie juga menyatakan ketidaksetujuannya jika embrio didonasikan kepada pasangan sesama jenis maupun pada seorang perempuan tidak menikah yang menginginkan anak.

"Jadi kalau didonasikan dengan permintaan yang jelas dengan izin dari bapak-ibunya mungkin bisa. Tetapi kalau misalnya, embrio itu didonasikan kepada rumah sakit atau di donasikan kepada negara misalnya begitu maka yang akan memberi izin itu tentu adalah negara itu atau rumah sakit itu. Tetapi tentu kita harapkan juga akan diberikan kepada pasutri yang membutuhkannya dan bukan untuk single parent. Karena single parent atau LGBT itu tidak diakui."(1050)

Donasi embrio yang berasal dari surplus embrio belum pernah terjadi sebelumnya di Indonesia. Meskipun 3 ilmuwan menyatakan setuju dengan opsi tersebut, hal ini masih banyak tantangan agar diterima semua pihak. Faktor legalitas adalah salah satu tantangannya.
Disisi lain, terminologi adopsi embrio sebagaimana terminologi adopsi anak, mungkin tidak tepat sama. ${ }^{11}$ Embrio masih harus melalui proses perkembangan dalam uterus wanita dan selanjutnya melalui tahap persalinan. Adopsi anak tidak melalui tahap kehamilan dan persalinan, maka terminologi adopsi embrio mungkin tidak dapat digunakan. Di sini, donasi embrio (pada pasangan infertil) dipandang sebagai opsi yang memberi penghormatan pada embrio sebagai suatu entitas hidup yang dapat berkembang menjadi insan dan merupakan pandangan yang solutif dan sebuah pemikiran keagamaan yang segar.

Pada donasi embrio mencakup 3 komponen, 1) pasangan yang mendonasikan, 2) pasangan yang menerima (inang), dan 3) fetus yang berkembang dari embrio donasi. ${ }^{10}$ Hak masing-masing komponen tersebut harus dilindungi.

Persiapan sebelum hamil embrio donasi juga merupakan hal yang harus dipertimbangkan selain masalah legalitas. Kehamilan pada ibu dengan embrio donasi bisa jadi menimbulkan masalah kesehatan seperti halnya kehamilan pada ibu dengan embrionya sendiri. Hiperemesis gravidarum (keluhan mual-muntah berlebihan pada ibu hamil yang bersifat patologis hingga menimbulkan komplikasi gangguan keseimbangan cairan tubuh, elektrolit atau gangguan fungsi organ) maupun preeklamsia (komplikasi akibat kehamilan yang ditandai dengan kenaikan tekanan darah disertai gangguan fungsi organ) mungkin pula bisa terjadi pada kondisi tersebut. Kesiapan mental ibu untuk hamil dengan embrio donasi semestinya sudah menjadi syarat sebelum embrio donasi ditanam ke rahim ibu inang. Aspek hukum akan menjadi lebih rumit ketika ibu hamil dari embrio donasi tersebut menginginkan aborsi karena alasan ketidaksiapan mental menghadapi efek samping kehamilan. Aspek hukum menjadi lebih ringan jika aborsi dilakukan karena kehamilan akan mengancam keselamatan ibu jika diteruskan.

Dilihat dari sisi agama Islam, terhadap donasi embrio yang berasal dari surplus embrio pada prosedur IVF, dapat diberlakukan hukum yang sesuai dengan hukum pada bayi/anak yang 
mendapat air susu ibu dari wanita bukan ibu genetiknya. Hal ini sesuai dengan pernyataan dari Prof Jenie. Para ilmuwan tersebut menyatakan bahwa orang tua genetik dari embrio harus diberitahukan kepadanya (embrio yang telah menjadi anak) kelak ketika dia siap menerima informasi tersebut. Hal ini untuk mencegah perkawinan sedarah dan juga untuk mengetahui penyakit tertentu yang diturunkan secara genetik dan penentuan hak waris harta (dalam aturan agama Islam).

"Nah ini juga terjadi perdebatan yang cukup lama ya tetapi kalau itu misalnya ada pasutri yang tidak bisa punya anak dan meminta embrio itu untuk diberikan kepada dia, pasangan suami istri yang sah, menurut saya, ini baru pendapat pribadi saya itu boleh. Artinya nanti anak itu hukumnya sama dengan anak sesusuan. Dia kan hanya embrio itu berasal dari pasanan suami istri yang sah masuk di pasutri yang infertil dan kemudian dilahirkan oleh dia. Maka ibunya itu adalah seperti ibu susuannya dia dengan hukum-hukum sama seperti itu." (1043)

\section{Donasi Surplus Embrio Untuk Penelitian}

Embrio yang digunakan untuk kepentingan penelitian jenis apa pun seperti penelitian stem cell, penelitian perkembangan embrio dan penelitian lainnya akan menyebabkan kerusakan embrio bahkan kematian. Keadaan ini tidak mudah diterima oleh sebagian ilmuwan bioetika. Dr. Kusmaryanto berkata,

"Oleh karenanya, biasanya pada umumnya atau CIOMS (Council for International Organizations of Medical Sciences) mengatakan research mempergunakan janin itu boleh kalau itu untuk kepentingan si embrio itu sendiri. Oleh karena tadi juga sudah dibicarakan mengenai intrinsic meaning tadi, intrinsic meaning. . . .masing-masing entitas yang ada di dunia ini itu mempunyai intrinsic meaning. "(1140)

Berdasarkan pendapat tersebut, Dr. Kusmaryanto menekankan segala tindakan yang menyebabkan kerusakan (do cause harm) tidak boleh untuk dilakukan. Perlakuan terhadap embrio hanya dibolehkan jika perlakuan tersebut bermanfaat bagi embrio itu sendiri seperti tindakan yang bertujuan untuk mengetahui defek pada sel/gen atau melakukan tindakan terapi.

Prof. Almirzanah bersikap lebih terbuka ketika menanggapi opsi surplus embrio untuk penelitian. Prof Almirzanah berkata,

"Nah kalau itu (embrio research) benefitnya itu tinggi, walaupun mungkin dhorornya (keburukannya), dhorornya mungkin ada dua tadi dhoror yang lebih dhoror yang pertama tadi membuang embrio banyak, bahayanya ..ee..atau keburukan. Dhoror yang lain adalah kalau orang sakit ini tidak diobati kan juga ada dhorornya. Nah sekarang dalam Islam bagaimana? Mana the least dhorornya itu. Mana yang paling sedikit keburukannya. Kalau keburukannya itu yang paling sedikit lalu benefitnya itu mungkin lebih banyak, why not?" (950)

Lebih lanjut Prof. Almirzanah berpendapat peneliti yang menggunakan embrio tersebut harus menimbang untung dan ruginya serta memilih yang memberikan sebanyak-banyaknya keuntungan dan serendah-rendahnya kerugian. Kerugian yang dimaksud adalah termasuk berapa banyak embrio yang dikorbankan untuk penelitian tersebut. Meskipun jumlah embrio yang dikorbankan untuk penelitian banyak, namun jika hasil yang didapat bisa menyelamatkan nyawa manusia, maka penelitian tersebut memberi banyak manfaat daripada kerugian. Disisi lain peneliti juga harus memiliki cultural competency (kompetensi budaya) karena budaya juga akan mempengaruhi cara pandang seseorang.

Agama Islam, seperti telah disebutkan di atas, memiliki banyak mazhab dan aliran. Shiah misalnya memberikan kelonggaran untuk dilakukan tindakan pada embrio dalam suatu penelitian bahkan membunuh/membuangnya sekalipun selama embrio tersebut berumur kurang dari 120 hari. Namun mazhab yang lain melarang untuk dibunuh meski embrio tersebut berumur kurang dari 120 hari. Sebagaimana yang disampaikan Prof. Jenie,

"Tahun 2002 WHO dilakukan suatu voting begitu apakah reproductive cloning itu diizinkan atau tidak. Apakah menggunakan embrio stem cell diizinkan atau tidak. Indonesia sebagai negara yang mayoritas penduduk Muslim nggak bisa menjawab itu sendiri. Tapi kalau 
negara dengan syiah di mana pimpinannya itu terpusat ia akan mengatakan bisa sebelum 120 hari. Sebaliknya negara yang ketat dengan Christianity yang cukup ortodoks akan mengatakan tidak, itu adalah suatu makhluk hidup atau paling tidak pro-life gitu. Nah Indonesia waktu itu bagaimana? Kita lalu mengiblat ke Saudi Arabia. Susah memang. Saudi Arabia mengatakan tidak boleh. Dia embrio stem cell tidak boleh."(993)

\section{Prediksi Keadaan Yang Berpotensi Konflik Terkait Manajemen Surplus Embrio}

Keberagaman agama, dan banyak aliran dalam satu agama kemungkinan menyebabkan perbedaan cara pandang dan persepsi bagi para pemeluknya terhadap opsi-opsi manajemen surplus embrio. Para dokter, embriolog, perawat dan teknisi laboratorium bisa jadi memeluk agama dan aliran yang berbeda satu sama lain. Begitu pula pada pasien yang memiliki surplus embrio simpan beku.

Dengan latar belakang agama dan aliran yang berbeda tersebut, maka para orang tua hendak memutuskan opsi mana yang akan dipilih, membutuhkan pertimbangan panjang dan memakan waktu lama. Mungkin juga mereka akan berada dalam situasi yang tidak nyaman dan merasa bingung. Peran konselor dalam hal ini sangat dibutuhkan untuk memberi panduan agar para orang tua lebih paham pada keputusan pilihan opsi mereka dan dampaknya di kemudian hari.

Lebih lanjut, para pelaksana opsi pilihan para orang tua tersebut juga memiliki latar belakang agama dan aliran berbeda. Konflik akan berlanjut lebih dalam ketika pelaksana harus membuang embrio sebagaimana pilihan orang tua, sementara dia sendiri tidak setuju dan berbeda pandangan dengan opsi tersebut. Dalam hal ini, perlu adanya kesepakatan antar pelaksana dalam menentukan siapa eksekutornya.

\section{KESIMPULAN}

Pertimbangan etika dalam manajemen surplus embrio di Indonesia terkait dengan agama yang dianut masyarakatnya, yang mayoritas adalah beragama Islam. Aliran dalam agama Islam perlu mendapat perhatian karena ada aliran bersifat liberal sampai konservatif sehingga perlu mengerti cara pandang masingmasing aliran keagamaan terhadap manajemen surplus embrio. Pemusnahan embrio dianggap sebuah opsi yang tidak etis oleh 3 ilmuwan yang memeluk agama Islam dan Katolik. Sedangkan opsi donasi embrio untuk riset masih mengandung banyak perdebatan. Opsi donasi surplus embrio untuk pasangan menikah infertil dapat diterima oleh ketiganya. Meski demikian, ketiga ilmuwan tersebut tidak bisa dianggap mewakili pendapat orang banyak di Indonesia, sehingga masih perlu dilakukan penelitian mendalam yang cukup mewakili pendapat rakyat Indonesia.

Pemberian informed consent secara terperinci menjadi hal prinsip sebelum diberikan tindakan pelayanan terkait teknologi reproduksi berbantuan, secara khusus terkait kemungkinan adanya surplus embrio dengan kualitas baik yang tidak/belum dikembalikan ke rahim istri.

\section{KONFLIK KEPENTINGAN}

Tidak ada konflik kepentingan dalam penelitian ini.

\section{UCAPAN TERIMA KASIH}

Penulis mengucapkan terima kasih kepada Assoc. Prof. Dr. Gabriele Werner-Felmeyer dari Biocentre Medical University of Innsbruck atas sumbang sarannya.

Karya tulis ini penulis persembahkan untuk Prof Umar Anggara Jenie yang telah meninggal dunia pada tanggal 26 Januari 2017.

Dr.C.B. Kusmaryanto, SCJ

Fakultas Teologi Universitas Sanata Dharma

Prof . Shafa'atun Almirzanah, MA, PhD

Fakultas Ushuludin dan Pemikiran Islam, Universitas Islam Negeri Sunan Kalijaga Yogyakarta

Prof Dr. Umar Anggara Jenie, Apt, MSc.

Fakultas Farmasi, Universitas Gadjah Mada 


\section{REFERENSI}

1. Human Fertilization and Embryology Authority. Fertility Facts and Figures 2008. Fertility Facts and Figures 2008. 2010.

2. Kemenkes. PERATURAN MENTERI KESEHATAN REPUBLIK INDONESIA NOMOR 43 TAHUN 2015. 2015;

3. Kemenkes. Peraturan Pemerintah Republik Indonesia No 61 Tahun 2014. 2014. p. 55.

4. Kerridge IH, Jordens CFC, Benson R, Clifford R, Ankeny RA, Keown D, et al. Religious perspectives on embryo donation and research. Clin Ethics. 2010;5(1):35-45. https:// doi.org/10.1258/ce.2009.009046.

5. Fuscaldo G, Russell S, Gillam L. How to facilitate decisions about surplus embryos: Patients' views. Hum Reprod. 2007;22(12):312938. https://doi.org/10.1093/humrep/dem325.

6. Wånggren K, Alden J, Bergh T, Skoog Svanberg A. Attitudes towards embryo donation among infertile couples with frozen embryos. Hum Reprod. 2013;28(9):2432-9. https://doi. org/10.1093/humrep/det252.

7. Banker M, Brinsden P, Buster J, Fiadjoe M, Horton M, Nygren K, et al. IFFS Surveillance 2013. Int Fed Fertil Soc. 2013;(October):1-148.

8. IFFS. IFFS Surveillance 2016. Vol. 0, International Federation of Fertility Societies Global Reproductive Health. 2016.

9. Sivaraman MAF, Noor SNM. Human Embryonic Stem Cell Research: Ethical Views of Buddhist, Hindu and Catholic Leaders in Malaysia. Sci Eng Ethics. 2016;22(2):467-85. https://doi.org/10.1007/s11948-015-9666-9.

10. Walters R. Embryo Adoption as an Ethical Option for Couples Faced With Infertility. Liberty University; 2016.

11. Daar J, Amato P, Benward J, Collins L, Davis J, Francis L, et al. Defining embryo donation: an Ethics Committee opinion. Fertil Steril. 2016;106(1):56-8. https://doi. org/10.1016/j.fertnstert.2016.03.017. 